\title{
Visible injury and nitrogen metabolism of rice leaves under ozone stress, and effect on sugar and protein contents in grain
}

\author{
Y.Z. Huang ${ }^{\mathrm{a}, *}$, L.H. Sui ${ }^{\mathrm{a}, \mathrm{b}}$, W. Wang ${ }^{\mathrm{c}}$, C.M. Geng ${ }^{\mathrm{c}}$, B.H. Yin ${ }^{\mathrm{c}}$ \\ ${ }^{a}$ Research Center for Eco-Environmental Sciences, Chinese Academy of Sciences, Beijing 100085, China \\ ${ }^{\mathrm{b}}$ Qingdao Safety Engineering Research Institute, China Petroleum E Chemical Corporation, Qingdao 266071, China \\ ${ }^{\mathrm{c}}$ Chinese Research Academy of Environmental Sciences, Beijing 100012, China
}

\section{H I G H L I G H T S}

Ozone stress caused obvious injury in rice leaves.

- Ozone stress had significant influence on the nitrate reductase activity in rice leaves.

- Sugar and protein contents in rice grain are influenced by ozone stress.

- The contents of albumin and glutenin in rice grain increased with increasing the ozone concentration.

\section{A R T I C L E I N F O}

\section{Article history:}

Received 16 July 2012

Received in revised form

31 August 2012

Accepted 1 September 2012

\section{Keywords:}

Ozone

Rice

Nitrate reductase

Starch

Protein

Grain

\begin{abstract}
A B S T R A C T
Effect of ozone on the visible injury, nitrogen metabolism of rice leaves, and sugar and protein contents in rice grain was carried out by the open-top chamber. The results indicated that ozone stress caused obvious injury in rice leaves. The increase in ozone concentration had significant influence on the nitrate reductase activity in rice leaves. At the ozone concentration of 40,80 and $120 \mathrm{~nL} \mathrm{~L}^{-1}$, the nitrate reductase activities in rice leaves in the tillering stage, the jointing stage, the heading stage and milk stage were separately reduced by $25.3-86.3 \%, 57.4-97.8 \%, 91.0-99.3 \%$ and $89.5-96.7 \%$ compared with those in the control treatment. As ozone concentration increased, the contents of ammonium nitrogen and nitrate nitrogen in rice leaves were obviously reduced. Ozone stress also had an influence on the contents of sugar and protein in rice grain. The stress of high ozone concentration $\left(120 \mathrm{~nL} \mathrm{~L}^{-1}\right)$ caused the starch content in grain to reduce by $15.8 \%$ than that in the control treatment, but total soluble sugars in grain was actually enhanced by $47.5 \%$ compared to that in the control treatment. The contents of albumin and glutenin in rice grain increased with increasing the ozone concentration, and prolamin and crude protein contents in rice grain increased only at the higher ozone concentration. Under ozone concentration of $120 \mathrm{~nL} \mathrm{~L}^{-1}$, the contents of albumin, glutenin and crude protein in rice grain were increased respectively by $23.1 \%, 21.0 \%$ and $21.1 \%$ compared with those in the control treatment. The result suggested that ozone tress has an influence on nitrogen metabolism of rice leaves and grain quality.
\end{abstract}

(c) 2012 Elsevier Ltd. All rights reserved.

\section{Introduction}

With the rapid growth of the world's population, the demand for economic development and energy propels people to constantly exploit and utilize fossil fuel and nitrogen fertilizer. As a result, the concentration of surface ozone increases constantly. Long-term monitoring shows that the ozone concentration in the troposphere of northern hemisphere increases by $1-2 \%$ annually, and ozone concentration of the polluted atmosphere is $100-200 \mathrm{~nL} \mathrm{~L}^{-1}$. The ozone concentration in the urban atmosphere is more than 10

\footnotetext{
* Corresponding author.

E-mail address: hyz@rcees.ac.cn (Y.Z. Huang).
}

times of the background concentration, and the maximum hourly concentration reaches as high as 200-400 $\mathrm{nL} \mathrm{L}^{-1}$ (Fishman, 1991). The monitoring statistics of ozone concentration of 86 monitoring sites in rural areas and remote regions of 35 states in the USA showed: there were 21.1 days year ${ }^{-1}$ with average daily value greater than $80 \mathrm{~nL} \mathrm{~L}^{-1}$; and the daily average value in the three months with the highest values was $54 \mathrm{~nL} \mathrm{~L}^{-1}$ (McCrady and Andersen, 2000). In Beijing-Tianjin-Tangshan area, the Yangtze Delta area and some other areas in China, the highest surface ozone concentration reaches more than $150 \mathrm{~nL} \mathrm{~L}^{-1}$ (Shao et al., 2006). Series ozone pollution is also discovered in other parts of the world (Coyle et al., 2003; Vingarzan, 2004a,b; Yamaji et al., 2006; Permadi and Oanh, 2008; Wang et al., 2009). Therefore, ozone pollution near 
ground level has become one of the major concerns for people (Vingarzan, 2004a,b; Selin et al., 2009).

High surface ozone concentration has great influence on farmland ecosystem, by directly or indirectly affecting the crop growth and yield. Many researches report that ozone stress may affect the activity of enzymes in plant antioxidant system (Mahalingam et al., 2006; Iriti and Faoro, 2008; Esposito et al., 2009) and the contents of non-enzyme materials (Holopainen and Kainulainen, 1997; Conklin and Barth, 2004; Singh et al., 2010), causing serious injury (Pina and Moraes, 2010; Sarkar and Agrawal, 2010). Ozone stress has great influence on the production of crops, and may cause a reduction in crop production of $5-15 \%$, or over $20 \%$ in some crops (Cho et al., 2011). The economic loss of crops caused by ozone stress in the US and European countries each year reaches 2-4 billion US dollars (Adams et al., 1988) and 4 billion Euros (Holland et al., 2002) respectively; that caused by high ozone concentration in the Yangtze Delta area of China is 1.475 billion RMB (Feng et al., 2003). There are also some researches into the influence of ozone stress on crop quality (Pleijel et al., 2006; Piikki et al., 2008), but little has been reported concerning the influence on crop nitrogen metabolism. Rice is the major food crop in the world; its total product ranks the third in the world. In China, the growth area of rice as the major food crop since 1980 approximately constitutes $23 \%$ of the world's total growth area of rice, and China's production of rice accounts for more than $30 \%$ of the world's total rice production (Liu, 2005). In this study, the open-top chamber (OTC) method was used to research and simulate the influence of increased ozone concentration on visible injury and nitrogen metabolism of rice leaves, the contents of sugar and protein in rice grain under farmland conditions. We also investigated the influence pattern of ozone stress on nitrogen cycle and grain quality of rice.

\section{Materials and methods}

\subsection{Experimental plot and materials}

The experimental plot is located in Dongguan Agricultural Seeds Research Institute in Guangdong Province $\left(23^{\circ} 1^{\prime} 21.97^{\prime \prime} \mathrm{N}\right.$, $\left.113^{\circ} 42^{\prime} 33.29^{\prime \prime} \mathrm{E}\right)$. Located in the northeast of the Pearl River Delta, this area is under the influence of subtropical monsoon climate, with long summer and short winter. The annual average temperature is $23.1^{\circ} \mathrm{C}$, and the annual average precipitation is $1819.9 \mathrm{~mm}$. Rice is the local major food crop. The variety studied was Oryza sativa L., provided by the Dongguan Agricultural Seeds Research Institute. The seeds were sown on March 3, 2009; seedling transplant began from March 29.

\subsection{Experimental design}

In-situ ozone fumigation experiment was carried out on rice with the self-made open-top fumigation system which was mainly composed of the open-top box, gas distribution system in the box, air blower, ozone generator, concentration control system and ozone analyzer (Fig. 1). With skeleton made of reinforcing steel bar, the open-top box was manufactured into an octahedron with a $45^{\circ}$ contracted aperture on top. The outside of the box was covered with transparent polyethylene thin film. The box had a side length of $1 \mathrm{~m}$, height of $2.7 \mathrm{~m}$ and the coverage area of approximately $4.8 \mathrm{~m}^{2}$. The ozone in the system was generated from the medical pure oxygen (99.5\%) through high-pressure discharge process in the ozone generator (SK-CFG-3, Jinan Sankang Envi-tech Co., Ltd.). The oxygen flow rate was adjusted with mass flowmeter (GFC17, Aalborg Industries Inc., Carson, CA) and Kingview industrial control software (MCGS 6.2, Beijing Kunlun Zhongda Industrial Control Technology Development Co., Ltd.), to control the ozone concentration in the system. The ozone concentration in the box and in natural atmosphere was continuously monitored with 2 ozone analyzers (Model 49c, Thermo Electron Co., Franklin, MA, Fig. 2). It was found through monitoring that the ozone concentration in the open-top fumigation system was quite stable and uniform. The standard deviation of the actual test data of ozone homogeneity $<4.4$, and coefficient of variation $<7.8 \%$. The variation tendency of the sampling point and the fixed control point was very consistent, which satisfied the requirement of this experiment.

4 ozone concentration treatments were set: ambient atmosphere ozone concentration (CK), 40, 80 and $120 \mathrm{~nL} \mathrm{~L}^{-1}$. 3 replicates were set for each treatment. Before the rice seedlings were transplanted, quicklime $\left(675 \mathrm{~kg} \mathrm{hm}^{-2}\right), \mathrm{P}_{2} \mathrm{O}_{5}\left(750 \mathrm{~kg} \mathrm{hm}^{-2}\right)$ and compound fertilizer $\left(\mathrm{N}: \mathrm{P}_{2} \mathrm{O}_{5}: \mathrm{K}_{2} \mathrm{O}=6: 5: 5,750 \mathrm{~kg} \mathrm{hm}^{-2}\right)$ were applied as the base fertilizer. After the rice seedling turned green, the self-made open-top chamber (OTC) was placed in the experimental plot. Urea $\left(150 \mathrm{~kg} \mathrm{hm}^{-2}\right)$ and compound fertilizer $\left(\mathrm{N}: \mathrm{P}_{2} \mathrm{O}_{5}: \mathrm{K}_{2} \mathrm{O}=6: 5: 5,60 \mathrm{~kg} \mathrm{hm}^{-2}\right.$ ) were additionally applied respectively on April 3, 2009 and May 11, 2009. The field management method during the entire growth period of rice was maintained consistent with that implemented in the locality. Ozone fumigation started from April 29, 2009, for $9 \mathrm{~h}$ (8:00-17:00) every day until July 11. Ozone fumigation stopped due to rainstorm or for other reasons during the experiment. When the experiment was ended, ozone fumigation was performed for a total of 44 days. The injury of rice leaves was carefully observed and recorded during the experiment. Fresh leaves were collected respectively in the tillering stage, the jointing stage, the heading stage and the milk stage.

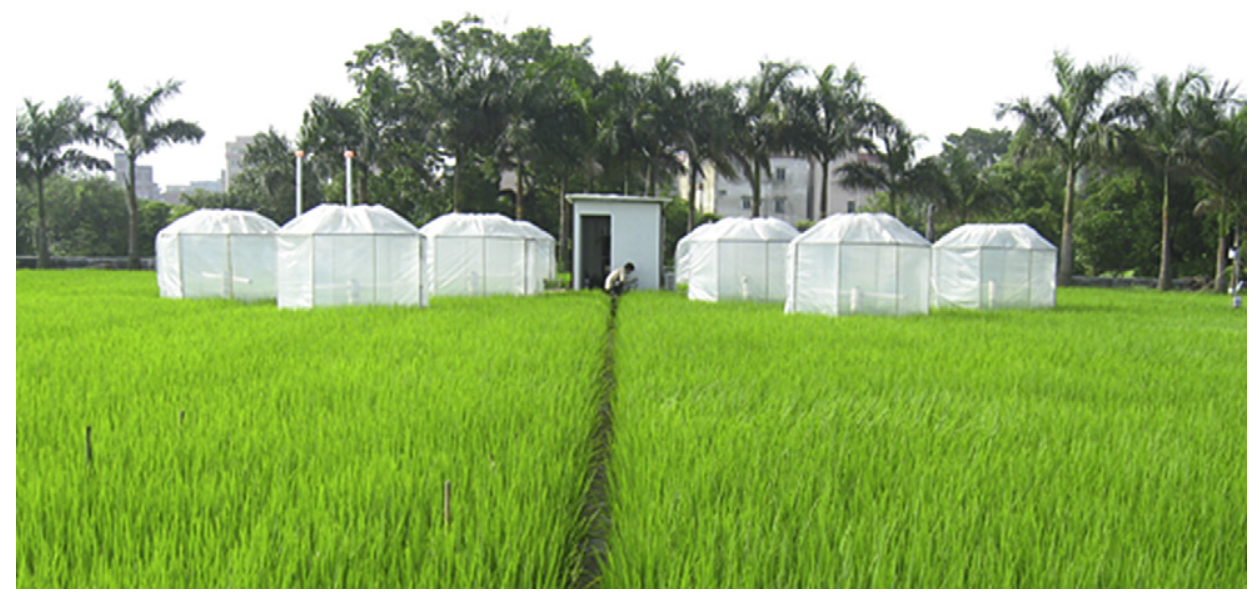

Fig. 1. Simulation experiment of ozone stress on rice grown in the field. 


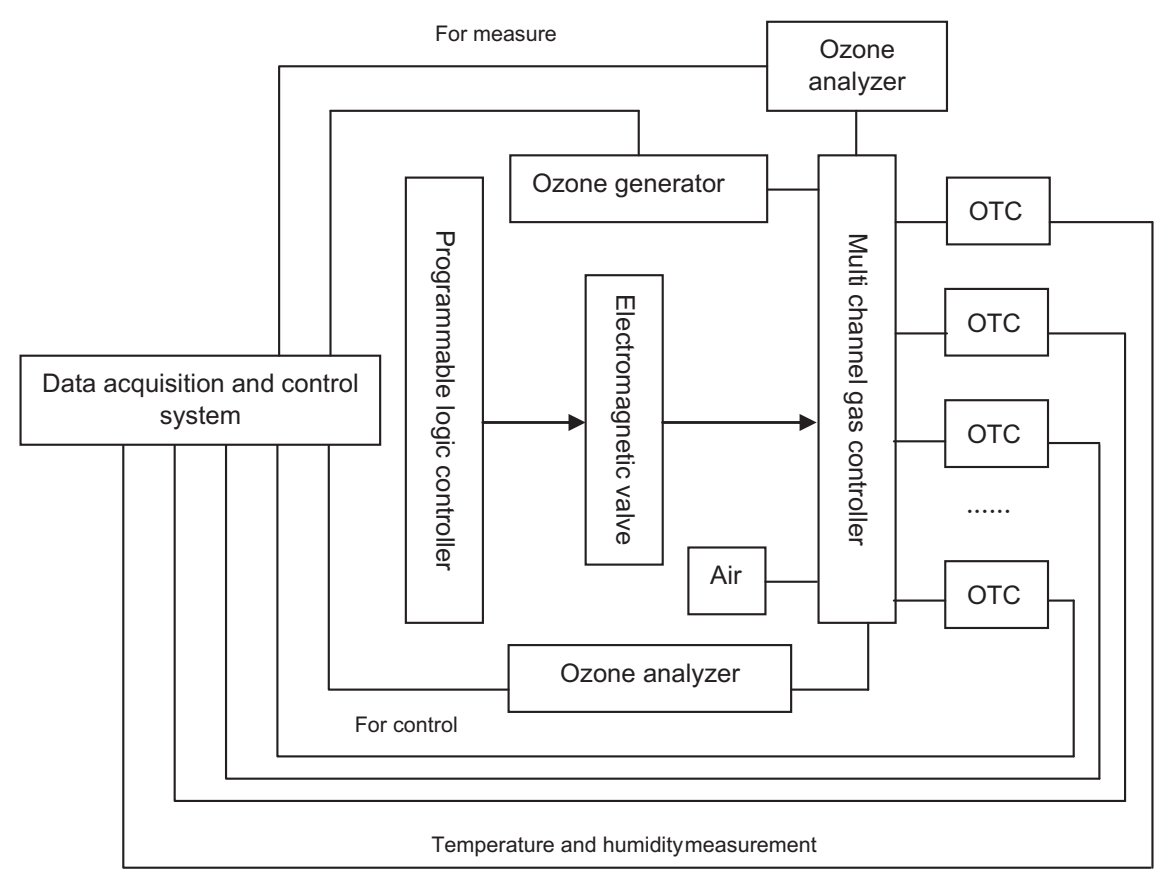

Fig. 2. Ozone automatic control and data acquisition system.

15-20 pieces of leaves were randomly collected each time, immediately put into liquid nitrogen after collection, and transferred to $-20^{\circ} \mathrm{C}$ refrigerator for storage prior to analysis. When the rice was mature, the grains were collected, dried at $70{ }^{\circ} \mathrm{C}$, peeled and crushed.

\subsection{Measurement}

Measurement of nitrate reductase activity: nitrate reductase activity was measured with the in vivo method. The specimens were washed with distilled water, and dried with filter paper. Wafers with the diameter of $1 \mathrm{~cm}$ were taken from the middle part of the leaves (or cut into small pieces of $0.5-1.0 \mathrm{~cm}^{2}$ ). After mixing, $0.5-1.0 \mathrm{~g}$ of each specimen was weighed and taken for three times, and placed in the test tubes and numbered. $9 \mathrm{~mL}$ of the mixture of $\mathrm{KNO}_{3}$, isopropyl alcohol and phosphate buffer solution was added to each tube. $1.0 \mathrm{~mL}$ of trichloroacetic acid was added immediately to one set of tubes, and mixed as the control treatment. Then all the test tubes were put into the vacuum dryer to exhaust air by vacuum pump. The procedure was repeated for several times until the leaves sank to the bottom of the tubes. Each tube was placed in the dark place and kept at $30{ }^{\circ} \mathrm{C}$ for $30 \mathrm{~min}, 1.0 \mathrm{~mL}$ of trichloroacetic acid was added to the processing tube, and shaken to terminate enzyme action. Each tube was left to stand for $2 \mathrm{~min} .2 \mathrm{~mL}$ of the supernatant was taken and added to another set of test tubes. Chromogenic determination was conducted with the standard curve method by taking the control tubes for reference. Enzyme activity was calculated.

Measurement of ammonium nitrogen and nitrate nitrogen contents: $0.5000 \mathrm{~g}$ of dried specimens were accurately weighed and placed in the bottom of the Kjeldahl flask. $6 \mathrm{~mL}$ of concentrated sulfuric acid was added into the flask, mixed well, and left to stand overnight. The specimen was heated slowly in the thermostat until white smoke appeared. The temperature was adjusted to be a little lower (for approximately $1 \mathrm{~min}$ ). 20 drops of $\mathrm{H}_{2} \mathrm{O}_{2}$ were added drop by drop, and the solution was heated continuously until it slightly boiled for a few minutes. Then the mixture was left to cool again, before the addition of a few drops of $\mathrm{H}_{2} \mathrm{O}_{2}$. The procedure was repeated for several times until the digested solution became completely clear. The solution was heated to slightly boil for $15 \mathrm{~min}$ in the last time to remove the residual $\mathrm{H}_{2} \mathrm{O}_{2}$. After cooling, $10 \mathrm{~mL}$ of ammonia-free water was added and the solution was transferred to a $50 \mathrm{~mL}$ volumetric flask to set the volume to graduation mark. The solution was transferred to a plastic vial, and placed in the refrigerator for preservation.

Measurement of ammonium nitrogen content: the digested solution was accurately diluted by 10 times with ammonia-free water ( $5 \mathrm{~mL}$ was taken to set the volume to $50 \mathrm{~mL}$ ). $0.5 \mathrm{~mL}$ of diluent (containing $1.5-2.5 \mathrm{mg} \mathrm{NH}_{4}^{+}$) was added to a $50 \mathrm{~mL}$ colorimetric tube; $1 \mathrm{~mL}$ of EDTA-methyl red solution was also added, with $\mathrm{pH}$ adjusted to approximately 6 by $0.3 \mathrm{~mol} \mathrm{~L}^{-1} \mathrm{NaOH}$ (methyl red changing from red to yellow). Next, $5 \mathrm{~mL}$ of phenol solution and $5 \mathrm{~mL}$ of sodium hypochlorite solution was added in sequence, and shaken well. The volume was set to graduation mark with water, and left to stand for above $1 \mathrm{~h}$. Ammonium nitrogen was measured by a UV spectrophotometer.

Measurement of nitrate nitrogen content: $5 \mathrm{~mL}$ of digested solution was added to a $50 \mathrm{~mL}$ colorimetric tube, diluted to the graduation mark with ammonia-free water, and shaken well. Nitrate nitrogen was measured at $210 \mathrm{~nm}$ by a UV spectrophotometer with $1 \mathrm{~cm}$ quartz cuvette, by taking ammonia-free water as a control.

Measurement of soluble sugars and starch content in grain: Anthrone colorimetry was used for the measurement of soluble sugars and starch content in grain. $0.2000 \mathrm{~g}$ of grain was weighed accurately and crushed; the grain specimens, after passing through a 60 -mesh sieve, were put into a $15 \mathrm{~mL}$ centrifuge tube. $5 \mathrm{~mL}$ of $80 \%$ ethanol solution was added, and the specimen was extracted in $80{ }^{\circ} \mathrm{C}$ water bath for $30 \mathrm{~min}$, with constant stirring. The glass rod was rinsed with a small amount of $80 \%$ ethanol, and the solution was cooled to room temperature and centrifuged at $3500 \mathrm{rpm}$ for $10 \mathrm{~min}$. The supernatant was transferred to a $25 \mathrm{~mL}$ volumetric flask to set the volume to graduation mark; $5 \mathrm{~mL}$ of $80 \%$ ethanol was added to precipitate again, and re-extracted for twice with the same method. The supernatant was combined in a $25 \mathrm{~mL}$ volumetric flask and diluted to the graduation mark. The extract could be used to measure the soluble sugars content. During the measurement, $2 \mathrm{~mL}$ of the diluent was taken after the specimen was diluted by 20 times. Anthrone-sulfuric acid reagent was added 
to the ice water bath, mixed well, put into $100{ }^{\circ} \mathrm{C}$ water bath and heated accurately for $10 \mathrm{~min}$. Then the specimen was taken out and cooled with tap water. The absorbance was determined at $620 \mathrm{~nm}$ by a spectrophotometer (optical path $0.5 \mathrm{~cm}$ ).

$2 \mathrm{~mL}$ of distilled water was added into the precipitate, and gelatinized in a boiling water bath for $15 \mathrm{~min}$. After cooling, $2 \mathrm{~mL}$ of $9.2 \mathrm{~mol} \mathrm{~L}^{-1}$ perchloric acid was added. After stirring for $15 \mathrm{~min}, 4 \mathrm{~mL}$ of distilled water was added and mixed well. The specimen was centrifuged at $3500 \mathrm{rpm}$ for $10 \mathrm{~min}$. The supernatant was transferred to a $50 \mathrm{~mL}$ volumetric flask. $2 \mathrm{~mL}$ of $4.6 \mathrm{~mol} \mathrm{~L}^{-1}$ perchloric acid was added into the precipitation again, and extracted under stirring for $15 \mathrm{~min} .5 \mathrm{~mL}$ of distilled water was added, and the specimen was centrifuged for $10 \mathrm{~min}$ after mixing. The supernatants obtained after two centrifugations were combined. The precipitate was washed twice with $5 \mathrm{~mL}$ of distilled water for each time. The supernatants were combined and the volume was set to graduation mark with distilled water. The extract obtained could be used to measure starch content using the method introduced above.

Measurement of protein content in grain: semi-automatic Kjeldahl nitrogen analyzer method was used for the measurement of crude protein content, which was calculated by multiplying the nitrogen content with 5.7. Continuous oscillation for extraction was performed to measure protein composition. $0.5 \mathrm{~g}$ of the specimen was weighed and put in a mortar. Albumin, globulin, gliadin and glutenin were extracted continuously with distilled water, $10 \% \mathrm{NaCl}, 75 \%$ ethanol and $0.2 \% \mathrm{NaOH}$ respectively. Then the content of each component was determined by semi-automatic

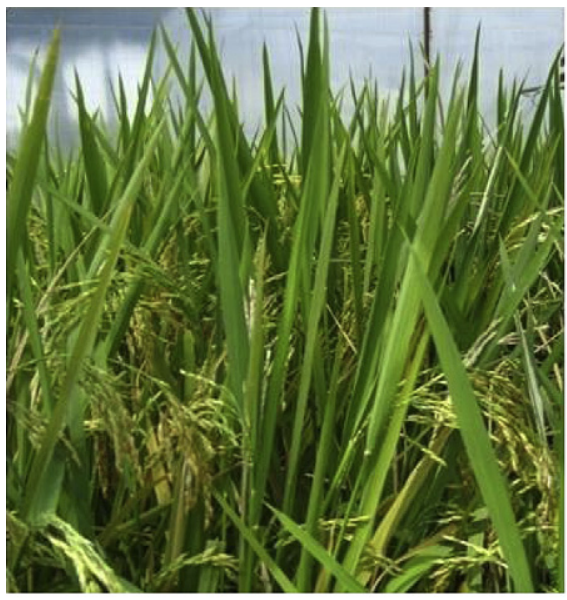

CK

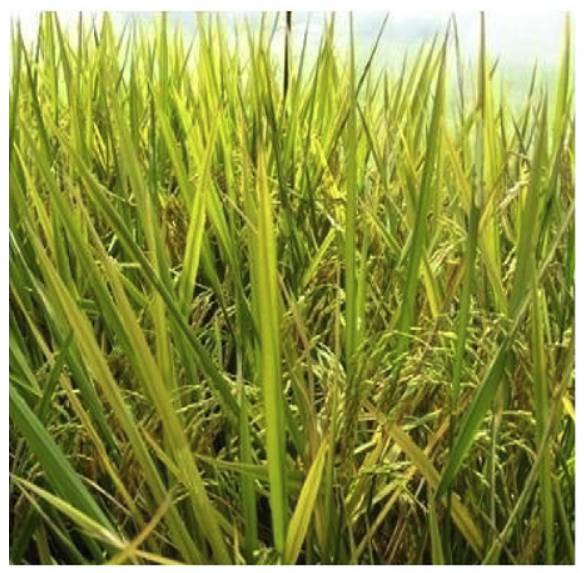

$80 \mathrm{~nL} \cdot \mathrm{L}^{-1}$
Kjeldahl nitrogen analyzer. The protein production was the product of grain production in unit area and crude protein content.

\subsection{Statistical analysis and processing}

SPSS 13.0 and origin 8.0 software were used for statistical analysis.

\section{Result}

\subsection{Visible injury of rice leaves}

The simulation results of ozone fumigation test indicated that obvious injury happened to rice leaves under ozone pollution stress. In the high-concentration treatment group (120 $\left.\mathrm{nL} \mathrm{L}^{-1}\right)$, leaf injury symptoms began to occur about a week after the fumigation began, with chlorosis of old leaf sheath, enlargement of leaf injury area and emergence of brown spots. At the later period of fumigation, almost all of the rice leaves withered, with etiolatedleaf sheath and small, etiolated rice spikes. Compared with that under ozone concentration of $120 \mathrm{~nL} \mathrm{~L}^{-1}$, decreased concentration of ozone significantly reduced injury symptoms of rice plants and delayed the emergence of leaf injury symptoms. However, with the prolonging of fumigation time, injury symptoms of rice leaves were further aggravated. Ozone stress caused rice maturity ahead of time.

Fig. 3 shows a group of photos during the milk stage. As we can see from this figure, ozone is harmful to rice leaves and the injury

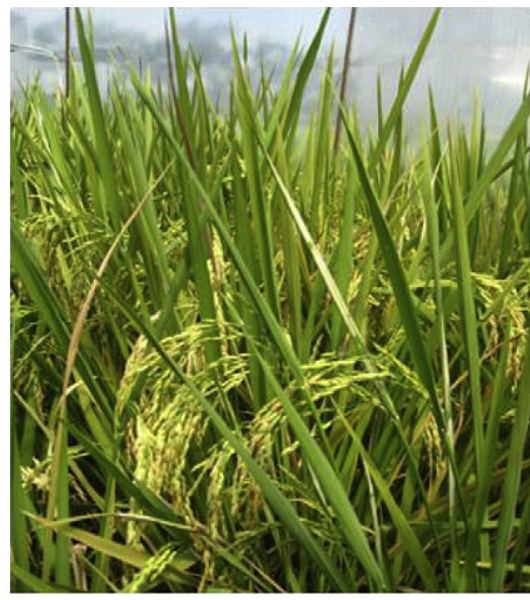

$40 \mathrm{~nL} \cdot \mathrm{L}^{-1}$

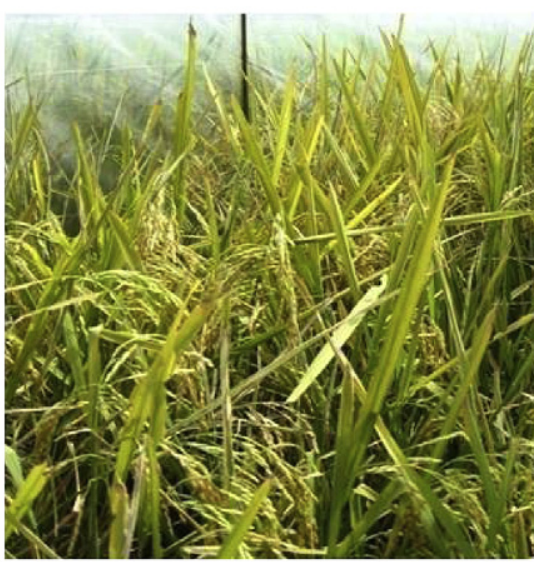

$120 \mathrm{~nL} \cdot \mathrm{L}^{-1}$

Fig. 3. Effects of elevated ozone concentrations on foliar symptom of rice (milk stage). 
brought about by different ozone concentration to rice plants differed. After the rice matured, ozone fumigation caused the grain to shrink and not full. During the entire fumigation test, fumigation was stopped for several times because of rain, so that some slightly injured rice leaves were given the time to recover. This phenomenon indicated that for rice plants under the stress of short-duration and low-concentration ozone fumigation, the injured tissues had selfrepair ability if the fumigation was stopped. However, in the case of high-concentration ozone fumigation, the injured rice leaves could no longer recover even if fumigation was stopped.

\subsection{Effect of ozone on nitrate reductase activity in rice leaves}

Fig. 4 shows the variation trend of nitrate reductase activity in rice leaves as ozone concentration increased at different growth stages. As we can see from this figure, at each sampling stage, nitrate reductase activity in rice leaves showed a significant decreasing trend with the increase of ozone concentration. Compared with the control treatment, at 40, 80 and $120 \mathrm{~nL} \mathrm{~L}^{-1}$ ozone concentration, the nitrate reductase activity was respectively reduced by $25.3 \%, 67.4 \%$ and $86.3 \%$ at tillering phase; $57.4 \%$, $75.7 \%$ and $97.8 \%$ at jointing stage; $91.0 \%, 97.2 \%$ and $99.3 \%$ at heading stage; $89.5 \%, 89.5 \%$ and $96.7 \%$ at milk stage. Nitrate reductase activity in rice leaves continually decreased with the increase of culture time. For example, in the control treatment, nitrate reductase activity in rice leaves at jointing stage, heading stage and milk stage was respectively reduced by $23.5 \%, 46.8 \%$ and $89.4 \%$ as compared with that at tillering stage. Similar variation trend was also observed under other ozone concentrations.

\subsection{Effect of ozone on ammonium nitrogen and nitrate nitrogen contents in rice leaves}

Figs. 5 and 6 respectively show the variation trends of ammonium nitrogen and nitrate nitrogen contents in rice leaves under the stress of ozone fumigation. As we can see from the two figures, ammonium nitrogen and nitrate nitrogen contents in rice leaves under the stress of ozone fumigation were both lower than those in the control treatment. At jointing stage, compared with the control treatment, nitrate nitrogen content in rice leaves at 40,80 and $120 \mathrm{~nL} \mathrm{~L}^{-1}$ was respectively reduced by $18.7 \%, 16.1 \%$ and $27.4 \%$; that of ammonium nitrogen was respectively was respectively reduced by $32.3 \%, 27.3 \%$ and $26.1 \%$. At milk stage, nitrate nitrogen content in rice leaves at 40,80 and $120 \mathrm{~nL} \mathrm{~L}^{-1}$, compared with the control treatment, was respectively reduced by $46.3 \%, 52.7 \%$ and $65.7 \%$, while that of ammonium nitrogen was respectively reduced by $6.5 \%, 12.9 \%$ and $43.4 \%$.

\subsection{Effect of ozone on sugars contents in grain}

Table 1 shows the variation trends of the sugar content in grain under the stress of ozone fumigation. We can see that the starch content in grain showed a decreasing trend with the increase of ozone concentration. Compared with the control treatment, the starch content in grain at 40,80 and $120 \mathrm{~nL} \mathrm{~L}^{-1}$ was respectively reduced by $6.7 \%, 8.8 \%$ and $15.8 \%$. The total soluble sugars in grain showed an increasing trend with the increase of ozone concentration. Such phenomenon was more apparent under higher ozone concentration. Total soluble sugars in grain at 80 and $120 \mathrm{~nL} \mathrm{~L}^{-1}$, compared with the control treatment, were respectively increased by $16.1 \%$ and $47.5 \%$. However, for starch content and total soluble sugars, significant difference $(p<0.05)$ as compared with the control treatment was only observed under higher ozone concentration $\left(120 \mathrm{~nL} \mathrm{~L}^{-1}\right)$.

\subsection{Effect of ozone on protein content in grain}

Table 1 also shows the effect of ozone concentration increase on protein in grain. We can see that albumin content in grain at 80 and $120 \mathrm{~nL} \mathrm{~L}^{-1}$, compared with the control treatment, was respectively

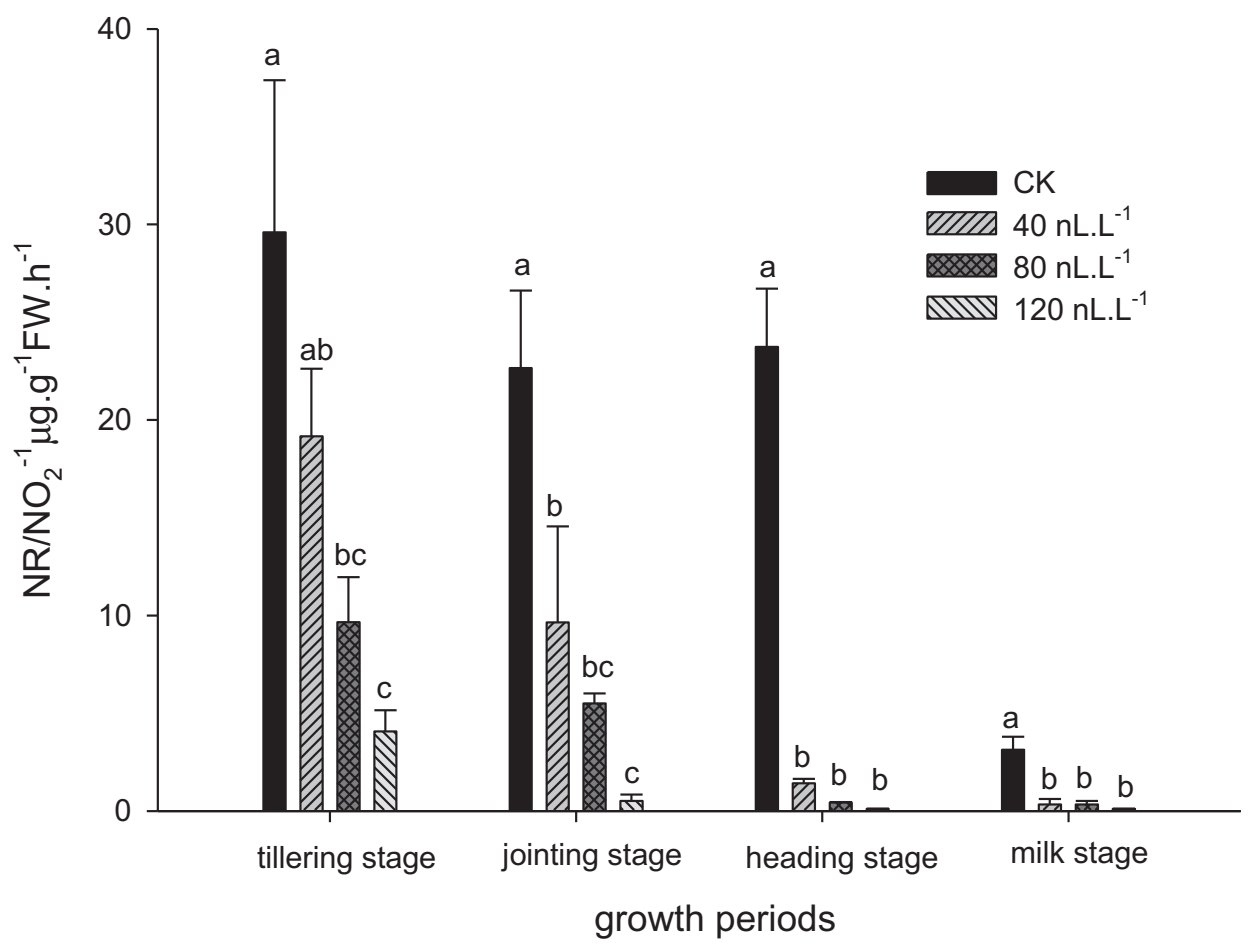

Fig. 4. Effect of ozone on nitrate reductase (NR) activity in leaves of rice. 


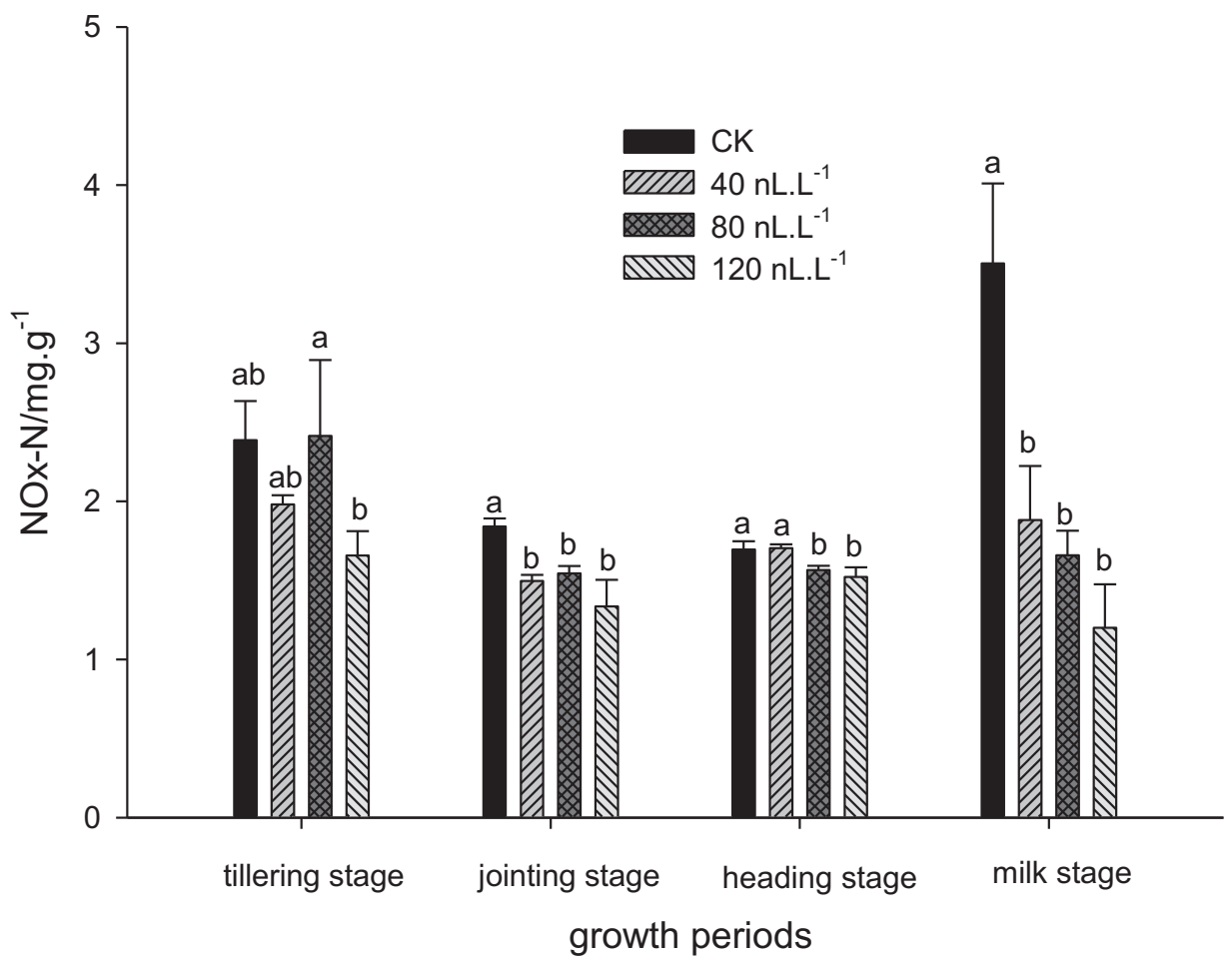

Fig. 5. Effect of ozone on $\mathrm{NO}_{x}-\mathrm{N}$ contents in leaves of rice.

increased by $21.5 \%$ and $23.1 \%$ ( $p<0.05$ ); there was no significant difference between globulin content in grain at $40-120 \mathrm{~nL} \mathrm{~L}^{-1}$ and that in the control treatment, but globulin content in grain significantly varied as ozone concentration changed between 80 and $120 \mathrm{~nL} \mathrm{~L}^{-1}(p<0.05)$. The gliadin and glutenin contents in grain under the stress of ozone fumigation both showed an increasing trend, and the variation trend of the latter was more significant $(p<0.05)$. Compared with the control treatment, the crude protein content in grain at 40,80 and $120 \mathrm{~nL} \mathrm{~L}^{-1}$ was respectively increased by $13.9 \%, 14.7 \%$ and $21.0 \%$. Only the increase by $21.1 \%$ in crude protein content in grain at $120 \mathrm{~nL} \mathrm{~L}^{-1}$ compared with that in the control group reached the significance level.

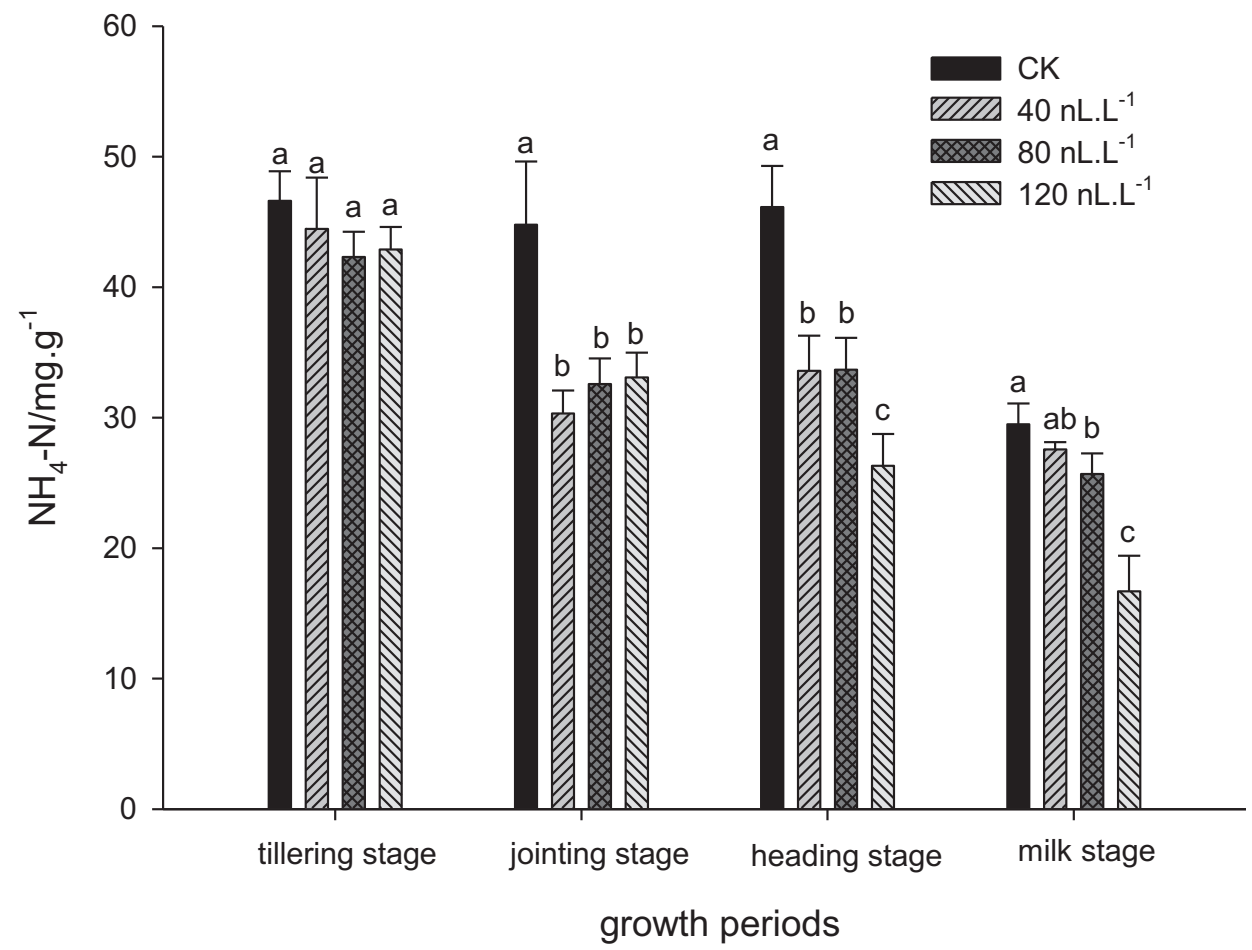

Fig. 6. Effect of ozone on $\mathrm{NH}_{4}-\mathrm{N}$ contents in leaves of rice. 
Table 1

Effect of ozone on protein and sugar contents in grain of rice.

\begin{tabular}{|c|c|c|c|c|c|c|c|}
\hline $\begin{array}{l}\text { Concentration } \\
\text { of } \mathrm{O}_{3}\left(\mathrm{~nL} \mathrm{~L}^{-1}\right)\end{array}$ & Albumin $\left(\mathrm{mg} \mathrm{g}^{-1}\right)$ & Globulin $\left(\mathrm{mg} \mathrm{g}^{-1}\right)$ & $\begin{array}{l}\text { Prolamin } \\
\left(\mathrm{mg} \mathrm{g}^{-1}\right)\end{array}$ & $\begin{array}{l}\text { Glutanin } \\
\left(\mathrm{mg} \mathrm{g}^{-1}\right)\end{array}$ & $\begin{array}{l}\text { Crude protein } \\
\left(\mathrm{mg} \mathrm{g}^{-1}\right)\end{array}$ & $\operatorname{Starch}\left(\mathrm{mg} \mathrm{g}^{-1}\right)$ & $\begin{array}{l}\text { Soluble sugar } \\
\left(\mathrm{mg} \mathrm{g}^{-1}\right)\end{array}$ \\
\hline CK & $40.99 \mathrm{~b}(1.38)^{*}$ & 24.35ab (1.17) & $14.74 b(0.37)$ & $30.52 c(0.33)$ & $121.16 \mathrm{~b}(1.03)$ & $758 a(24.77)$ & $12.22 \mathrm{bc}(0.68)$ \\
\hline 40 & $42.52 b(0.44)$ & $27.15 a(0.85)$ & $17.24 \mathrm{a}(0.53)$ & $34.75 b(0.50)$ & $125.16 \mathrm{~b}(5.88)$ & 707.6ab (28.93) & $10.83 c(0.14)$ \\
\hline 80 & $49.81 \mathrm{a}(1.22)$ & $28.31 \mathrm{a}(2.47)$ & $17.77 \mathrm{a}(0.99)$ & $35.00 \mathrm{~b}(0.19)$ & $123.74 b(2.72)$ & 691.2ab (14.13) & $14.19 \mathrm{~b}(0.70)$ \\
\hline 120 & 50.47a (2.24) & $21.10 \mathrm{~b}(0.42)$ & $17.35 a(0.28)$ & $36.91 a(0.63)$ & $141.84 \mathrm{a}(3.69)$ & $638.4 \mathrm{~b}(21.18)$ & $18.03 a(0.32)$ \\
\hline$p$ value & $p<0.01$ & $p<0.05$ & $p<0.05$ & $p<0.001$ & $p<0.05$ & $p<0.05$ & $p<0.001$ \\
\hline $\mathrm{LSD}_{0.05}$ & 4.73 & 4.67 & 1.95 & 1.44 & 12.14 & 74.87 & 1.70 \\
\hline
\end{tabular}

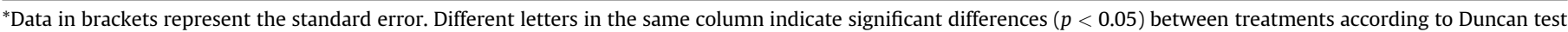
multiple comparison.

\section{Discussions}

High concentration ozone stress can cause injury to rice leaves, including leaf sheath chlorosis, injury area enlargement, brown spot emergence and finally, kraurosis. Long-duration and lowconcentration ozone stress can also cause similar injury to crop plants. Ozone concentration increase will aggravate ozone-related injury to crop. There is report which finds that spinach under ozone stress will show obvious injury symptoms, including the appearance of light yellow spots on leaf tip, leaf midrib's two flanks, leaf edge and petiole, which will finally become dark brown with kraurosis; leaf tips of some tender leaves will curl and their leaf edges will crumple up. The leaves will feel to be thinned softened, with serious dehydration (Yao et al., 2007). Research on ozonerelated injury in 3 species of ligneous plant in southern China found that the leaves of Eucalyptus urophylla, Aglaia odorata and Pinus massoniana under ozone stress showed brown spots, became curly or thinned and suffered from kraurosis (Huang et al., 2006). In addition, other researchers have also reported the injury of ozone pollution stress to plants (Pina and Moraes, 2010; Sarkar and Agrawal, 2010).

Nitrate reductase is a rate-limiting enzyme in nitrogen assimilation in higher plants, which can directly regulate nitrate reduction, thereby regulating nitrogen metabolism and influencing photosynthetic carbon metabolism. Nitrate reductase activity is related to various metabolic processes of plants and their physiological indicators. As an inducible enzyme, it can be easily affected by light, temperature, moisture, $\mathrm{CO}_{2}$, molybdenum content and nitrate concentration. Exogenous hormone analogs can also influence nitrate reductase activity. Effect of such environmental conditions such as light on nitrate reductase activity in plants has been researched (Lillo, 1994). But the effect of ozone pollution stress on nitrate reductase activity in plants has been rarely reported. In this experiment, ozone fumigation decreased nitrate reductase activity in rice leaves, and a reduction nitrate nitrogen and ammonium nitrogen contents. This finding was consistent with the research results of $\mathrm{CO}_{2}$ 's effect on nitrogen metabolism in plants (Johnson et al., 2000). $\mathrm{CO}_{2}$ concentration increase can reduce nitrate reductase activity and the nitrate nitrogen and ammonium nitrogen contents in the aboveground parts of winter wheat. The reason for this phenomenon can be attributed to the fact that increased $\mathrm{CO}_{2}$ concentration enhances nitrate nitrogen metabolism in plants, with more production of nitrogen-containing organic compounds (Men and $\mathrm{Li}, 2005$ ). Ozone pollution stress can reduce nitrate reductase activity because ozone-related injury inhibits the growth of rice plant, which affects its various metabolic functions. As a consequence, nitrate nitrogen and ammonium nitrogen contents are reduced.

The finding that starch content in grain decreased with the increase of ozone concentration was consistent with that in other researches (Fuhrer et al., 1990). But the difference in starch content in grain was only significant compared with the control group at higher ozone concentration ( $120 \mathrm{~nL} \mathrm{~L}^{-1}$ ), i.e. a reduction of $15.8 \%$. The reasons might include the coming of reproduction stage ahead of time, shortened grain-filling stage, and insufficient grain-filling under ozone stress (Liu et al., 2009). Such phenomenon was more obvious under higher ozone concentration. Under ozone stress, the rice leaves would enter senescence earlier, which influenced the synthesis and accumulation of carbohydrates such as starch (Sild, 1999). In addition to this, ozone could also inhibit the sugar's transfer from the crop stems and leaves to the grain, influencing the synthesis of starch in grain by blocking the starch source (Schnyder, 1993). Total soluble total sugars in grain content at $120 \mathrm{~nL} \mathrm{~L}^{-1}$, compared with that in the control treatment, was increased by $47.5 \%$. Total soluble sugars, as the substrate for starch synthesis, is closely related to starch content. Reduced starch accumulation corresponds with the increasing trend of total soluble sugars. Such phenomenon is more obvious in rice. We can believe that there are certain associations between starch content and total soluble sugar. However, the associations may be very complex.

The protein content in grain increased with ozone concentration increase, probably for the following reasons: at the initial stage of grain growth, nitrogen accumulation was faster and fewer carbohydrates were accumulated. That accumulated in the cortex accounted for a larger proportion and it had higher protein content than endosperm (Cao and Wang, 1994). At the later stage of grainfilling, carbohydrate accumulation dominated in the grain. However, ozone stress caused the rice plant to enter senescence earlier and shortened grain-filling stage, so that the accumulation of such carbohydrates as starch was reduced and the starch's dilution effect on the protein decreased (Piikki et al., 2008). Therefore, the protein content increased with the ozone concentration increase, whereas the starch content showed a decreasing trend, which was consistent with previous analysis on starch content variation trend. At the same time, the finding that the thousand seed weight decreased with the increase of ozone concentration (the research result of another research team) also confirmed our result. The accumulation of albumin and globulin was concentrated at the initial stage of grain-filling, while gliadin and glutelin were synthesized later (Cao and Wang, 1994). There has been report (Liu et al., 2009) which found that under ozone stress, the crop plant would complete its earlier growth stage, while the grain-filling stage was shortened. Therefore, the albumin and globulin contents at the early stage of growth were relatively higher, while gliadin and glutelin contents at the later stage were reduced. But we did not reach similar conclusions in our experiment, which might be related to different crop varieties selected. Extensive studies indicate that gliadin plays a primary role in determining the extensibility of dough, while glutenin is an important influence factor for dough elasticity; albumin and globulin contents represent the nutrient quality of proteins (Stone et al., 1997; Wesley et al., 2001). The effect on grain quality of rice requires further analysis by considering the crop yield. 


\section{Conclusion}

Rice plants under ozone pollution stress showed obvious injury symptoms: chlorosis, brown spot and kraurosis of old leaf sheaths, small and etiolated rice spikes, shrunken grain and rice maturity stage a head of time. With an increasing ozone concentration, nitrate reductase activity and the nitrate nitrogen and ammonium nitrogen contents in rice leaves were significantly reduced, compared with the control treatment. At 40,80 and $120 \mathrm{~nL} \mathrm{~L}^{-1}$, nitrate reductase activity in rice leaves at heading stage and milk stage was respectively decreased by $91.0-99.3 \%$ and $89.5-96.7 \%$ compared with the control group; nitrate nitrogen and ammonium nitrogen contents in rice leaves at the jointing stage were respectively reduced by $18.7-27.4 \%$ and $26.1-32.3 \%$ compared with the control group.

Starch content and total soluble sugars in grain responded differently under ozone stress. Under higher ozone concentration $\left(120 \mathrm{~nL} \mathrm{~L}^{-1}\right)$, starch content in grain was significantly reduced by $15.8 \%$ as compared with the control treatment, while total soluble sugars in grain was significantly increased by $47.5 \%$. Ozone stress also influenced the protein content in grain, but the influence degree differed for different protein components. Ozone stress could increase albumin and globulin contents, and higher ozone concentration also significantly increased gliadin and crude protein contents in rice grain.

\section{Acknowledgments}

This work was supported by the National Natural Science Foundation of China (No. 41071336), the Environmental Protection Commonweal Trade Scientific Research of China (200809152), and by the Knowledge Innovation Project of the Chinese Academy of Sciences (No. KSCX2-YW-N-41-05).

\section{References}

Adams, R.M., Glyer, J., Mccarl, B., 1988. The NCLAN economic assessment: approach, findings and implications. In: Heck, W.W., Taylor, O.C., Tingey, D.T. (Eds.), Assessment of Crop Loss from Air Pollutants. Elsevier, London, pp. 473-504.

Cao, G.C., Wang, X.Z., 1994. Quality and Ecology for Wheat. China Science and Technology Press, Beijing, pp. 48-56 (in Chinese).

Cho, K., Tiwari, S., Agrawal, S.B., Torres, N.L., Agrawal, M., Sarkar, A., Shibato, J., Agrawal, G.K., Kubo, A., Rakwal, R., 2011. Tropospheric ozone and plants: absorption, responses, and consequences. Reviews of Environmental Contamination and Toxicology 212, 61-111.

Conklin, P., Barth, C., 2004. Ascorbic acid, a familiar small molecule intertwined in the response of plants to ozone, pathogens, and the onset of senescence. Plant, Cell \& Environment 27, 959-970.

Coyle, M., Flower, D., Ashmore, M.R., 2003. New directions: implications of increasing tropospheric background ozone concentrations for vegetation. Atmospheric Environment 37, 153-154.

Esposito, M.P., Ferreira, M.L., Sant'Anna, S.M., Domingos, M., Souza, S.R., 2009. Relationship between leaf antioxidants and ozone injury in Nicotiana tabacum 'Bel-W3' under environmental conditions in São Paulo, SE-Brazil. Atmospheric Environment 43, 619-623.

Feng, Z.W., Jin, M.H., Zhang, F.Z., Huang, Y.Z., 2003. Effects of ground-level ozone $\left(\mathrm{O}_{3}\right)$ pollution on the yields of rice and winter wheat in the Yangtze River Delta. Journal of Environmental Sciences 15, 360-362.

Fishman, J., 1991. The global consequence of increasing tropospheric ozone concentration. Chemosphere 22, 685-695.

Fuhrer, J., Lehnherr, B., Moeri, P.B., Tschannen, W., Shariat-Madari, H., 1990. Effects of ozone on the grain composition of spring wheat grown in open-top field chambers. Environmental Pollution 65, 181-192.

Holland, M., Mills, G., Hayes, F., 2002. Economic Assessment of Crop Yield Losses from Ozone Exposure. Part of the UNECE International Cooperative Programme on Vegetation, Progress Report (April 2001-March 2002) Contract EPG, 1, 170.
Holopainen, J., Kainulainen, P., 1997. Growth and reproduction of aphids and levels of free amino acids in Scots pine and Norway spruce in an open-air fumigation with ozone. Global Change Biology 3, 139-147.

Huang, Y.Y., Huang, Y.Z., Li, Q.X., 2006. Physiological and foliar symptom response of Pinus massoniana, Eucalyptus urophylla and Aglaia odorata to ozone in southern China. Ecology and Environment 15, 674-681 (in Chinese).

Iriti, M., Faoro, F., 2008. Oxidative stress, the paradigm of ozone toxicity in plants and animals. Water, Air, and Soil Pollution 187, 285-301.

Johnson, D., Cheng, W., Ball, J., 2000. Effects of $\mathrm{CO}_{2}$ and $\mathrm{N}$ fertilization on decomposition and $\mathrm{N}$ immobilization in ponderosa pine litter. Plant and Soil 224, 115-122.

Lillo, C., 1994. Light regulation of nitrate reductases in green leaves of higher plants. Physiologia Plantarum 90, 616-620.

Liu, H.J., Zheng, Y.F., Wu, R.J., Zhao, Z., Hu, C.D., Shi, C.H., 2009. Impacts of increasing surface ozone on growth and yield of winter wheat in Nanjing area. Chinese Journal of Agrometeorology 30, 195-200 (in Chinese).

Liu, S.C., 2005. Production and demand of rice in China. Grain Issues Research 3,1618 (in Chinese)

Mahalingam, R., Jambunathan, N., Gunjan, S.K., Faustin, E., Weng, H., Ayoubi, P. 2006. Analysis of oxidative signalling induced by ozone in Arabidopsis thaliana. Plant, Cell \& Environment 29, 1357-1371.

McCrady, J.K., Andersen, C.P., 2000. The effect of ozone on below-ground carbon allocation in wheat. Environmental Pollution 107, 465-472.

Men, Z.H., Li, S.X., 2005. Effect of $\mathrm{CO}_{2}$ concentration on nitrogen metabolism of winter wheat. Scientia Agricultura Sinica 38, 320-326 (in Chinese).

Permadi, D.A., Oanh, N.T.K., 2008. Episodic ozone air quality in Jakarta in relation to meteorological conditions. Atmospheric Environment 42, 6806-6815.

Piikki, K., De Temmerman, L., Ojanperä, K., Danielsson, H., Pleijel, H., 2008. The grain quality of spring wheat (Triticum aestivum L.) in relation to elevated ozone uptake and carbon dioxide exposure. European Journal of Agronomy 28 245-254.

Pina, J.M., Moraes, R.M., 2010. Gas exchange, antioxidants and foliar injuries in saplings of a tropical woody species exposed to ozone. Ecotoxicology and Environmental Safety 73, 685-691.

Pleijel, H., Berglen Eriksen, A., Danielsson, H., Bondesson, N., Selldén, G., 2006. Differential ozone sensitivity in an old and a modern Swedish wheat cultivargrain yield and quality, leaf chlorophyll and stomatal conductance. Environmental and Experimental Botany 56, 63-71.

Sarkar, A., Agrawal, S.B., 2010. Identification of ozone stress in Indian rice through foliar injury and differential protein profile. Environmental Monitoring and Assessment 161, 205-215.

Schnyder, H., 1993. The role of carbohydrate storage and redistribution in the source sink relations of wheat and barley during grain filling in a review. New Phytologist 123, 233-245.

Selin, N.E., Wu, S., Nam, K.M., Reilly, J.M., Paltsev, S., Prinn, R.G., Webster, M.D., 2009 Global health and economic impacts of future ozone pollution. Environmental Research Letters 4, 1-9.

Shao, M., Tang, X., Zhang, Y., 2006. City clusters in China: air and surface water pollution. Frontiers in Ecology and the Environment 4, 353-361.

Sild, E., 1999. Impact of Increasing Concentrations of $\mathrm{O}_{3}$ and $\mathrm{CO}_{2}$ on Wheat, Clover and Pasture. Ph.D. thesis, Tartu University, ISBN 9985-56-427-8.

Singh, E., Tiwari, S., Agrawal, M., 2010. Variability in antioxidant and metabolite levels, growth and yield of two soybean varieties: an assessment of anticipated yield losses under projected elevation of ozone. Agriculture, Ecosystems and Environment 135, 168-177.

Stone, P.J., Gras, P.W., Nicolas, M.E., 1997. The influence of recovery temperature on the effects of a brief heat shock on wheat III: grain protein composition and dough properties. Journal of Cereal Science 25, 129-141.

Vingarzan, R., 2004a. A review of surface ozone background levels and trends. Atmospheric Environment 38, 3431-3442.

Vingarzan, R., 2004b. A review of Surface ozone background levels and trends. Atmospheric Environment 38, 3431-3442.

Wang, T., Wei, X.L., Ding, A.J., Poon, C.N., Lam, K.S., Li, Y.S., Chan, L.Y., Anson, M., 2009. Increasing surface ozone concentrations in the background atmosphere of Southern China, 1994-2007. Atmospheric Chemistry and Physics 9, 62176227.

Wesley, A.S., Lukow, O.M., McKenzie, R., Ames, N., Brown, D., 2001. Effect of multiple substitutions of glutenin and gliadin proteins on flour quality of Canada prairie spring wheat. Cereal Chemistry 78, 69-73.

Yamaji, K., Ohara, T., Uno, I., Tanimoto, H., Kurokawa, J., Akimoto, H., 2006. Analysis of seasonal variation of ozone in the boundary layer in East Asia using the Community Multiscale Air Quality model: what controls surface ozone level over Japan? Atmospheric Environment 40, 1856-1868.

Yao, F.F., Wang, X.K., Feng, Z.Z., 2007. Influence of ozone and ethylenediurea (EDU) on physiological characters and foliar symptom of spinach (Spinacia oleracea L.) in open-top chambers. Ecology and Environment 16, 1399-1405 (in Chinese). 